\title{
COUNTRY-SPECIFIC EMISSION FACTORS FOR BIOMASS COMBUSTION IN RESIDENTIAL AND AGRICULTURE SECTORS
}

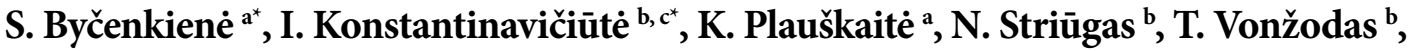 \\ M. Sadeckas ${ }^{b}$, N. Pedišius ${ }^{b}$, R. Juodka ${ }^{d}$, R. Juška ${ }^{d}$, and V. Juškiené ${ }^{d}$ \\ ${ }^{a}$ Center for Physical Sciences and Technology, Savanoriu 231, 02300 Vilnius, Lithuania \\ ${ }^{\mathrm{b}}$ Lithuanian Energy Institute, Breslaujos 3, 44403 Kaunas, Lithuania \\ ${ }^{c}$ Kaunas University of Technology, Studentu 48, 51367 Kaunas, Lithuania \\ ${ }^{\mathrm{d}}$ Institute of Animal Science of LUHS, R. Žebenkos 12, 82317 Baisogala, Lithuania \\ Email: steigvile.bycenkiene@ftmc.lt
}

Received 30 October 2018; revised 26 March 2019; accepted 2 April 2019

\begin{abstract}
In this research carbon monoxide (CO), nitrogen oxides $\left(\mathrm{NO}_{x}\right)$, non-methane volatile organic compounds (NMVOC), ammonia $\left(\mathrm{NH}_{3}\right)$ and total suspended particles (TSP) were measured, and national emission factors (EF) were determined. Although biomass is commonly used in the residential sector and releases a large part of pollutants in the atmosphere, due to lack of well-documented investigations on air pollutants EFs of wood burning it is difficult to set up representative country-specific emission factors in Lithuania. This study is focused on biomass combustion in the residential sector in order to provide data for country- and technology-specific national EFs. The study has estimated EFs of $\mathrm{CO}, \mathrm{NO}_{x}, \mathrm{NMVOC}$, TSP and $\mathrm{NH}_{3}$ from biomass burning in the residential and agriculture sectors, respectively, using four-step methodology according to the exhaust gas analysis.
\end{abstract}

Keywords: national emissions, emission factor, residential, energy, biomass, agriculture

PACS: 88.05.Np, 88.05.Rt, 88.20.dj, 88.05.Lg, 87.23.-n

\section{Introduction}

The increasing problems of transboundary air pollution led to the signature of the Convention on Longrange Transboundary Air Pollution (CLRTAP) by the United Nations Economic Commission for Europe (UNECE). The result of this joint effort has been remarkable: emissions of a series of harmful substances have been reduced by 40 to $80 \%$ since 1990 in Europe. In line with the priorities set in the long-term strategy for the CLRTAP, sciencebased decision making associated with the effects-

\footnotetext{
${ }^{*}$ Equal contributions
}

oriented approach will remain necessary, therefore strengthening the connection between policy and science in the period 2018-2019 will aim to make an additional progress identified in the long-term strategy. One important part of the scientific work is to provide relevant data on country- and technology-specific EFs and to improve their quality, transparency, consistency and completeness.

Lithuania annually reports air pollutant emissions to the Secretariat of the UNECE Convention on Long-range Transboundary Air Pollution and to the European Environment Agency (EEA). Until now, much of the Lithuania air pollution measurements provide data gathered together with fuel 
combustion data and default EFs from the European Monitoring and Evaluation Programme EMEP/ EEA Guidebook (2016) to make the national emission estimation on the lowest Tier 1 level. However, external experts strongly recommended that each Member State should set a priority on country- or technology-specific EFs. Despite this, Lithuania uses the default EFs since it lacks its own research findings.

Residential heating is critical energy service needed worldwide. Even with a large accessibility of electricity and natural gas, the utilization of biomass burning for residential heating continues to be mostly practised in Lithuania. Biomass heating fuels consist primarily of wood and can also include wood waste and agricultural residues. Most fuels are burned in low capacity boilers. Open fireplaces are also popular in many households. In general, the highest share of biomass for heating is burned in stoves that incompletely combust the fuel due to low combustion temperature and other technological limitations resulting in higher emissions of many products from incomplete combustion, such as $\mathrm{CO}, \mathrm{NO}_{x}$, NMVOC and TSP. In Lithuania nearly all residential heating devices have chimneys, so most of the emissions release directly to the atmosphere and contribute to air pollution locally. Another reason for concern arises from climate and energy policies. The problem is that many countries are actively encouraging residential heat- ing with biomass as this type of fuel is publicised as a renewable fuel which supports climate change mitigation. Moreover, biomass as fuel was also included in the European Commission's strategy for reaching the '20-20-20' targets (20\% reduction in emissions, $20 \%$ of final energy consumption from renewable energy and 20\% increase in energy efficiency by 2020) [1]. As a negative result, biomass combustion in the residential sector is rising in some countries owing to wrong government incentives and subsidies and the public opinion that it is a 'green' option (Table 1). Further reasons for concern are economic downturns and fuel switching from gas to solid ones [2].

In Lithuania there are no direct government incentives for residential heating with biomass, but historically biomass dominates in the structure of fuel consumed in the residential sector due to comparatively low prices in comparison to natural gas.

The biggest part of ammonia emissions is related to agricultural activity. Livestock farming is responsible for the bulk of ammonia emission from agriculture. The largest part of ammonia, emitted from animal husbandry, evaporates from cattle housing. The review of the Lithuania inventory reported under CLRTAP was performed in 2017. Necessity to reveal scientifically based national technology-/country-specific emission factors was stated by the recommendations of the EC International Expert Board.

Table 1. Examples of government incentives and subsidies for residential heating with wood [3-4].

\begin{tabular}{|c|c|c|}
\hline Country (instrument) & Incentive/subsidy & Notes on implementation \\
\hline $\begin{array}{l}\text { Denmark (Incentive to Scrap } \\
\text { Pre-1980 Wood Boilers) }\end{array}$ & $\begin{array}{l}\text { Grant of }<€ 530 \text { for households replac- } \\
\text { ing old wood boilers with new boilers } \\
\text { meeting the emission limit }(2008-2009)\end{array}$ & $\begin{array}{l}\text { 3,500 wood boilers have been } \\
\text { replaced - about twice what would } \\
\text { have been expected without the grant }\end{array}$ \\
\hline $\begin{array}{c}\text { Germany (Market Incentive } \\
\text { Programme) }\end{array}$ & $\begin{array}{c}\text { Subsidy for installation of pellet boilers } \\
\text { (over } 150 \mathrm{~kW} \text { ) of }>€ 2,000 \text { or } 2,500 \\
\text { when combined with solar panels }\end{array}$ & $\begin{array}{l}\text { The programme is more than a dec- } \\
\text { ade old; designated funding has been } \\
\text { adjusted downwards in some years }\end{array}$ \\
\hline $\begin{array}{c}\text { Norway } \\
\text { (Ban on Electrical and Oil } \\
\text { Heating in New Buildings; } \\
\text { 40\% of heat demand in new } \\
\text { buildings must be supplied by } \\
\text { non-grid electricity or } \\
\text { non-fossil fuel energy) }\end{array}$ & $\begin{array}{c}\text { Subsidies of } 20 \% \text { for purchase of a new } \\
\text { pellet stove }(<€ 490) \text { or a new pellet } \\
\text { boiler }(<€ 1,225)\end{array}$ & $\begin{array}{l}\text { The fund from which these subsidies } \\
\text { come totalled } € 4.3 \text { billion in } 2013 \\
\text { was managed in part by Enova SF, } \\
\text { a state-run company }\end{array}$ \\
\hline $\begin{array}{c}\text { United Kingdom (2014 } \\
\text { Domestic Renewable Heat } \\
\text { Incentive) }\end{array}$ & $\begin{array}{l}\text { Household tariff from the Govern- } \\
\text { ment of } 12.2 \mathrm{p}(€ 0.15) \text { per } \mathrm{kW} \text { hour of } \\
\text { energy generated when biomass boilers } \\
\text { and pellet stoves are used to heat home }\end{array}$ & $\begin{array}{c}\text { As of August } 2014,>1,600 \text { household } \\
\text { biomass-fuelled home heating sys- } \\
\text { tems had been approved to partici- } \\
\text { pate in this programme }\end{array}$ \\
\hline
\end{tabular}




\section{Methodology}

The methodology for calculating the EF through actual measurements consisted of four steps. The first step is non-CO concentration $\left(\mathrm{mg} \mathrm{m}^{-3}\right)$ and volume flow rate $\left(\mathrm{Nm}^{3} \mathrm{~h}^{-1}\right)$ determination, and conducting unit conversion to calculate the emission factor. The second one is standardising the heating value ( $\mathrm{GJ} \mathrm{h} \mathrm{h}^{-1}$ ) and fuel consumption $\left(\mathrm{kg} \mathrm{h}^{-1}\right)$. The third step is estimation of emissions over a given period $\left(\mathrm{mg} \mathrm{h}^{-1}\right)$. In the fourth step, the amount of non-CO emissions is calculated by entering the heating value of fuel and determination of the EFs $\left(\mathrm{g} \mathrm{GJ}^{-1}\right)$. For $\mathrm{CO}$, emissions can be fairly estimated based on the amount of fuels combusted and the averaged carbon content of fuel because it mainly depends upon the carbon content of fuel (as well as $\mathrm{RH}$, calorific values). However, emissions of $\mathrm{NO}_{x}$, NMVOC and TSP can be influenced by numerous additional factors, such as combustion technology and operating conditions.

The concentration of by-combustion products was measured by portable gas analysers Testo 350XL and FTIR Gasmet DX-4000, absorption tubes and a 7890A GC series Agilent Quadrupole mass spectrometre gas chromatograph; TSP mass was measured by an automatic isokinetic sampling system (Isostack Basic, TCR Tecora, Milan, Italy). The equipment was calibrated before the experiments.
During the study period, nine case studies were performed with three different types of residential heating equipment ( 3 manual stoves, 4 automatic stoves and 2 fireplaces).

The determination of ammonia emissions from the tie-stalls and cubicle loose housing cowsheds was carried out based on the ventilation rate. Evaluation was made according to moisture and carbon dioxide balance methods [5-6] and field experiments in the farms and farm environment.

Microclimate measurements were carried out in the cattle sheds and in the farm environment. For the experiments devices ALMEMO 2890-9 (Ahlborn Mess- und Regelungstechnik GmbH, Germany), Dräger X-am 7000 (Dräger Safety AG \& Co., Germany) and M40 (Industrial Scientific Corporation, USA) were used to analyse the environmental conditions (air temperature, relative air humidity, carbon dioxide and ammonia concentrations). The dynamic chamber and passive chamber methods [8-9] for studying ammonia emissions from manure storage were applied. Data related to the amounts of nitrogen in diet were obtained on the basis of nutrition standards [9].

\section{Results and discussion}

\subsection{Situation in Lithuania}

Tendencies of fuel consumed in the residential sector are presented in Fig. 1. As seen from Fig. 1,

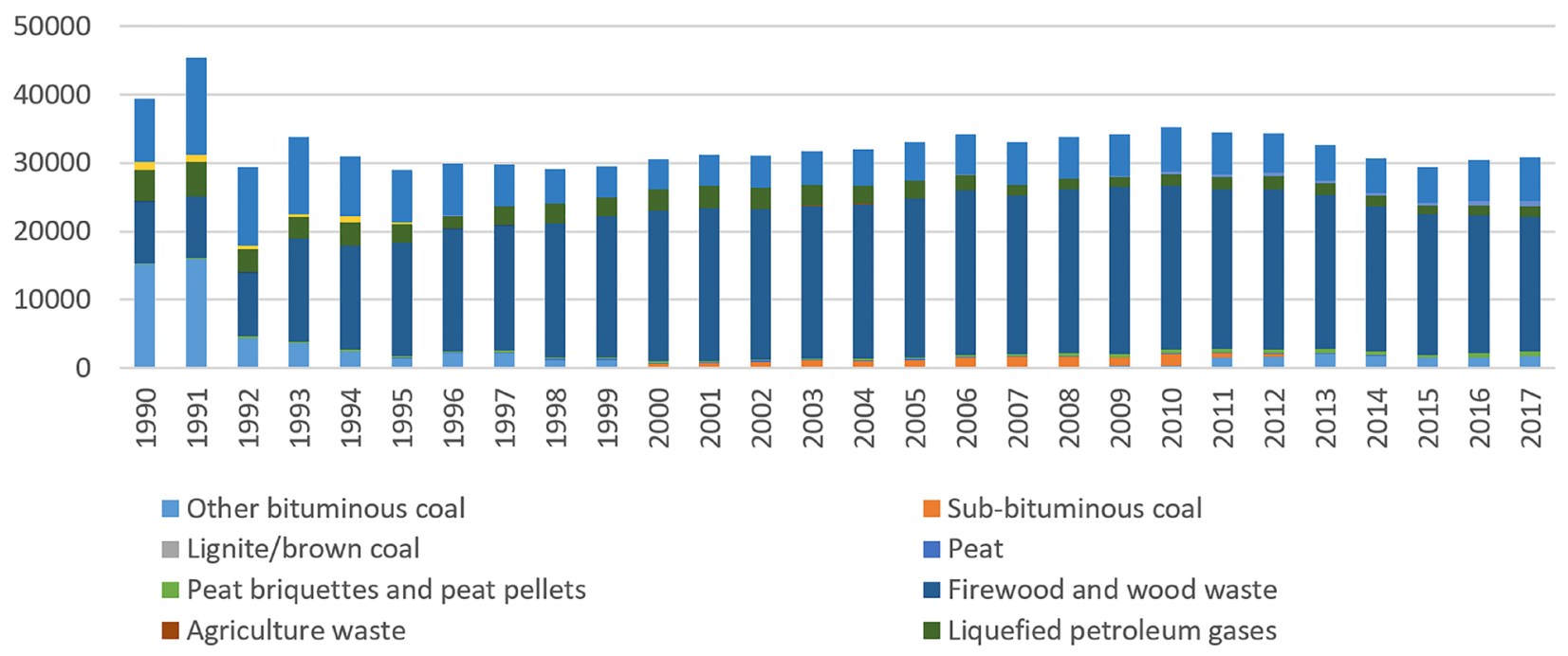

Fig. 1. The structure of fuel consumed in the residential sector in 1990-2017 (data from Statistics Lithuania, 2018). 
biomass fuel dominates in the structure of fuel consumed in the residential sector. In $2017 \sim 3$ million tonnes of fuel were consumed, where biomass accounted for $70.0 \%$, natural gas for $17.5 \%$, solid fuels for $6.7 \%$ and liquid fuels for $5.8 \%$ of the fuel structure in 2017 (Fig. 1). It means that the estimated technology-/country-specific EFs will influence about $70 \%$ of national inventory emissions in the most problematic sector regarding pollution abatement.

In the residential sector, biomass combustion equipment technology varies depending on the fuel type, application, design and organization of the combustion process. Continuous improvement of the design of the combustion process has led to the emergence of new, more advanced technologies that deliver higher productivity and lower emissions. Such advanced technologies are characterised by high-efficiency traditional furnaces, improved fuels (including eco-labelling of wood stoves) and pellet stoves. Biomass combustion boilers $(<50 \mathrm{~kW})$ are commonly used in residential homes for simple operation and low investment costs. Insufficient fuel combustion occurs due to non-optimized air supply, therefore, when combustion is operated under low load, emissions can be higher. Advanced fuel combustion boilers have a similar design and fuel combustion as a conventional boiler, but the installed fan controls the exhaust flow, ensuring the pollution efficiency control of over $80 \%$. In recent years, households are increasingly using condensing boilers, which provide an even higher efficiency (90\%). The principle of a condensing boiler is based on the extraction of additional heat from the condensation of water vapour (from exhaust gases).

\subsection{Residential sector}

In this study, to identify the emission characteristics of $\mathrm{CO}$ and non-CO ( $\mathrm{NO}_{x}$, NMVOC, TSP) pollutants and develop EFs from biomass combustion boilers $(<50 \mathrm{~kW})$, three heating devices were selected (Table 2). However, the emission characteristics of $\mathrm{NO}_{x}$, NMVOC and TSP EFs differ depending on combustion conditions, such as technology, $\mathrm{RH}$ and calorific value. Therefore, it is difficult to use the emission factor produced from the fuel analysis (EMEP/EEA 2016) as a representative value for Lithuania. Thus, this study used the experimentally measured emission gas concentration to calculate the national EFs. The samples were collected from the units of the boilers under operation and nine

Table 2. CO, $\mathrm{NO}_{x}, \mathrm{NMVOC}$ and TSP EFs and the selected boiler type/capacity.

\begin{tabular}{|c|c|c|c|c|c|c|}
\hline \multirow{2}{*}{ Source } & \multirow{2}{*}{$\begin{array}{l}\text { Capacity, } \\
\text { kW }\end{array}$} & \multirow{2}{*}{ Combustion equipment } & \multicolumn{4}{|c|}{ Emission factor, g/GJ } \\
\hline & & & $\mathrm{CO}$ & $\mathrm{NO}_{x}$ & NMVOC & TSP \\
\hline \multirow{4}{*}{$\begin{array}{l}\text { Study } \\
\text { results }\end{array}$} & \multirow{4}{*}{$16-50$} & \multirow{4}{*}{$\begin{array}{c}\text { Automatic } \\
\text { (wood, wood residual) }\end{array}$} & 370.3 & 90.5 & 9.1 & - \\
\hline & & & 120.2 & 81.4 & 8.1 & 10.7 \\
\hline & & & 154.7 & 121.7 & 2.4 & 11.1 \\
\hline & & & 763.0 & - & 51.3 & 36.1 \\
\hline $\begin{array}{l}\text { EMEP/EEA } \\
\text { GB, } 2016\end{array}$ & $<50 \mathrm{~kW}$ & & 300 & 80 & 10 & $30\left(\mathrm{PM}_{2.5}\right)$ \\
\hline \multirow{3}{*}{$\begin{array}{l}\text { Study } \\
\text { results }\end{array}$} & \multirow{3}{*}{$20-25$} & \multirow{3}{*}{$\begin{array}{c}\text { Manual } \\
\text { (wood, wood residual) }\end{array}$} & 655.8 & 118.8 & 31.6 & 9.1 \\
\hline & & & 1405.9 & 79.5 & 19.2 & 9 \\
\hline & & & 3147.0 & - & 411.9 & 19.2 \\
\hline $\begin{array}{l}\text { EMEP/EEA } \\
\text { GB, } 2016\end{array}$ & $<50 \mathrm{~kW}$ & & 4000 & 80 & 350 & $140\left(\mathrm{PM}_{2.5}\right)$ \\
\hline \multirow{2}{*}{$\begin{array}{c}\text { Study } \\
\text { results }\end{array}$} & \multirow{2}{*}{$6-8$} & \multirow{2}{*}{ Fireplaces (wood) } & 843.1 & 43.92 & 44.5 & 15.2 \\
\hline & & & 3098.1 & 33.86 & 115.1 & 19.3 \\
\hline $\begin{array}{l}\text { EMEP/EEA } \\
\text { GB, } 2016\end{array}$ & $<50 \mathrm{~kW}$ & & 4000 & 50 & 600 & $240\left(\mathrm{PM}_{2.5}\right)$ \\
\hline $\begin{array}{l}\text { Ireland, } \\
2015\end{array}$ & & & $2762-6258$ & - & - & $373-1135$ \\
\hline
\end{tabular}


samples were taken. Table 2 shows the $\mathrm{CO}, \mathrm{NO}_{x}$, NMVOC and TSP EFs of each boiler type.

The non-CO EFs range from 38.9 to 121.7, from 2.4 to 411.9 and from 9.0 to $36.1 \mathrm{~g} \mathrm{GJ}^{-1}$ for $\mathrm{NO}_{x}$, NMVOC and TSP, respectively. As expected, CO EFs per unit type varied in a broad range from 120.2 to $3147.0 \mathrm{~g} \mathrm{GJ}^{-1}$. This is because each boiler has different operational conditions, amount of fuel consumed per amount of heat generated and emission flow rate of exhaust gas. While CO EFs depend on the chemical composition and physical properties of biomass according to several factors, which can be divided into three groups: 1) type of biomass burnt, 2) biomass growing conditions (climate, geolocation, soil type) and 3) biomass
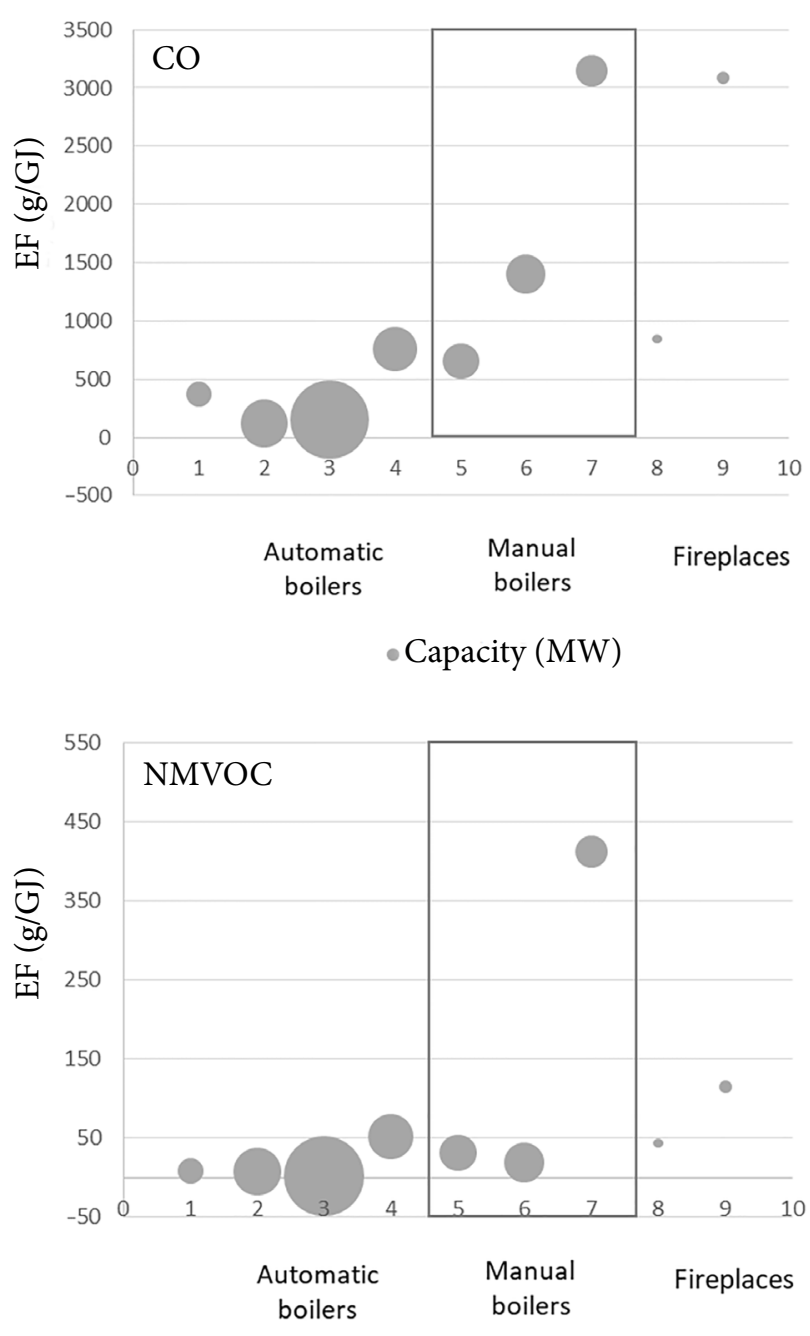

- Capacity (MW) harvesting and treating [10]. For this study, we optimised the capacity, amount of fuel consumed and the emission flow rate each time when samples were taken to calculate the non-CO EF of a solid fuel combustion boiler in the Lithuanian residential sector.

As shown in Table 2, which presents EFs calculated during the research, the mean $\mathrm{NO}_{x} \mathrm{EF}$ is $44 \mathrm{~g} \mathrm{GJ}^{-1}$. This value is by $14 \%$ lower than the technology-specific default $\mathrm{NO}_{x} \mathrm{EF}\left(50 \mathrm{~g} \mathrm{GJ}^{-1}\right)$ of 'automatic boilers using wood as an energy source, as the EMEP/EEA Guidebook (2016) suggests. NMVOC EF was found to be $79.8 \mathrm{~g} \mathrm{GJ}^{-1}$ for fireplaces, burning wood and wood waste, that is considerably lower than the default $\left(600 \mathrm{~g} \mathrm{GJ}^{-1}\right)$ value,

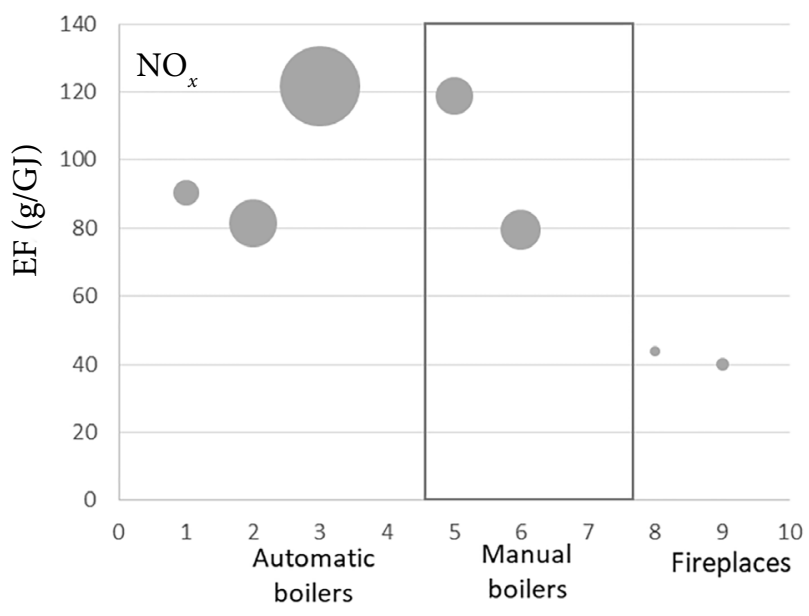

- Capacity (MW)

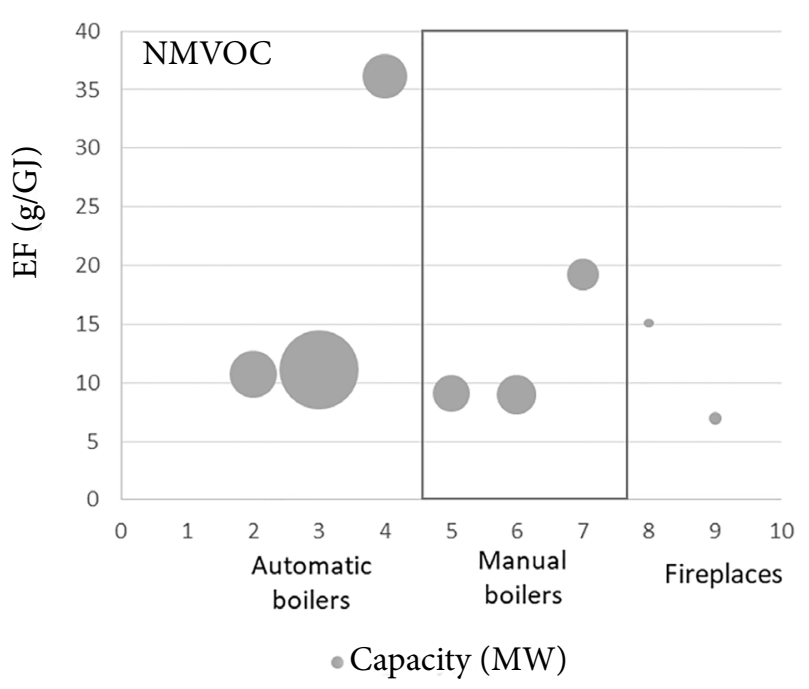

Fig. 2. Estimated $\mathrm{CO}, \mathrm{NO}_{x^{\prime}}$ NMVOC and TSP EFs for residential biomass combustion equipment $(<50 \mathrm{~kW})$. 
but also corresponds to the default limits (20$3000 \mathrm{~g} \mathrm{GJ}^{-1}$ ) provided by the EMEP Guidebook (2016). The experimental values of EF in the manual $\left(32 \mathrm{~g} \mathrm{GJ}^{-1}\right)$ and automatic boilers $\left(9 \mathrm{~g} \mathrm{GJ}^{-1}\right)$ are lower than the default values (350 and $10 \mathrm{~g} \mathrm{GJ}^{-1}$, respectively), but fall within the limits (100-2000 and 1-30 $\mathrm{g} \mathrm{GJ}^{-1}$, respectively). Analogous results were obtained for the $\mathrm{PM}_{2.5} \mathrm{EF}$ values. The research study on Ireland fireplaces in 2015 illustrated that $\mathrm{CO}$ ranged from 2762 to $6258 \mathrm{~g} \mathrm{GJ}^{-1}$, with black poplar producing the greatest emissions and pellet fuels producing $3151 \mathrm{~g} \mathrm{GJ}^{-1}$. For $\mathrm{PM}_{2.5}$ the range was from 373 to $1135 \mathrm{~g} \mathrm{GJ}^{-1}$ with the greatest emissions coming from olive and pellet fuels producing $649 \mathrm{~g} \mathrm{GJ}^{-1}$.

A literature review shows that a large range of $\mathrm{CO} \mathrm{EF}$ values can be explained by the sample moisture content, which reduces the burnable constituents in the fuel and affects the wood combustion process: delays fuel ignition, extends drying time, decreases fuel combustion heat and affects efficiency [11-12]. It should be noted that at the same time the completely dry wood combustion does not provide the maximum efficiency as has been shown by [13].

\subsection{Agriculture sector}

Typically, the emissions of ammonia and other pollutants are calculated using the methodology and the emission factors provided in the EMEP/ CORINAIR Emission Inventory Guidebook. However, specific emission factors, applicable in this methodology, are based on data from re- searchers of various countries and often may not correspond to the country's situation. For example, the total ammoniacal nitrogen excretion varied from $58 \%$ in Austria to $84 \%$ in the Netherlands [14]. In our study, the excretion of total ammonia nitrogen by animal was equal to $62.5 \pm 3.17 \%$. Traditionally cows in the tie-stall housing system are kept about 220 days in buildings. However, lately part of farmers prefer housing systems based on the zero access to pasture. Due to the manure fraction that remains on pasture the ammonia emissions from manure management in tie-stall housing systems are lower by $49.3-47.1 \%$ than those of cubicle loose housing systems (Fig. 3).

Average emission rates of $\mathrm{NH}_{3}$ per animal over the stall housing period in the cubicle loose housing are $45 \%$ lower than those in the tie-stall housing. Over the stall housing period, the tie-stall and cubicle loose housing gave a range of emission rates of 19.4-58.0 $\mathrm{g} \mathrm{animal}^{-1} \mathrm{~d}^{-1}$ in winter and summer periods, respectively. Similarly, the averaged emission of $\mathrm{NH}_{3}$ during the 220-day period for the cubicle loose housing is by $38 \%$ lower compared with that of the tie-stall housing. The calculated emissions of the tie-stall, cubicle loose 220-day and 365-day housing periods amounted

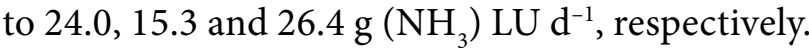
According to Bleizgys and Baležentienè (2014) [15], the emissions from tie-stall and cubicle loose housing were 27.4 and $21.9 \mathrm{~g} \mathrm{LU} \mathrm{d}^{-1}$, respectively.

On average, the evaluated $\mathrm{NH}_{3}-\mathrm{N}$ flux was 2.6 and $2.0 \mathrm{~g} \mathrm{~m}^{-2} \mathrm{~d}^{-1}$ for liquid and solid manure, respectively. However, the emission from solid manure is higher due to a higher surface area.

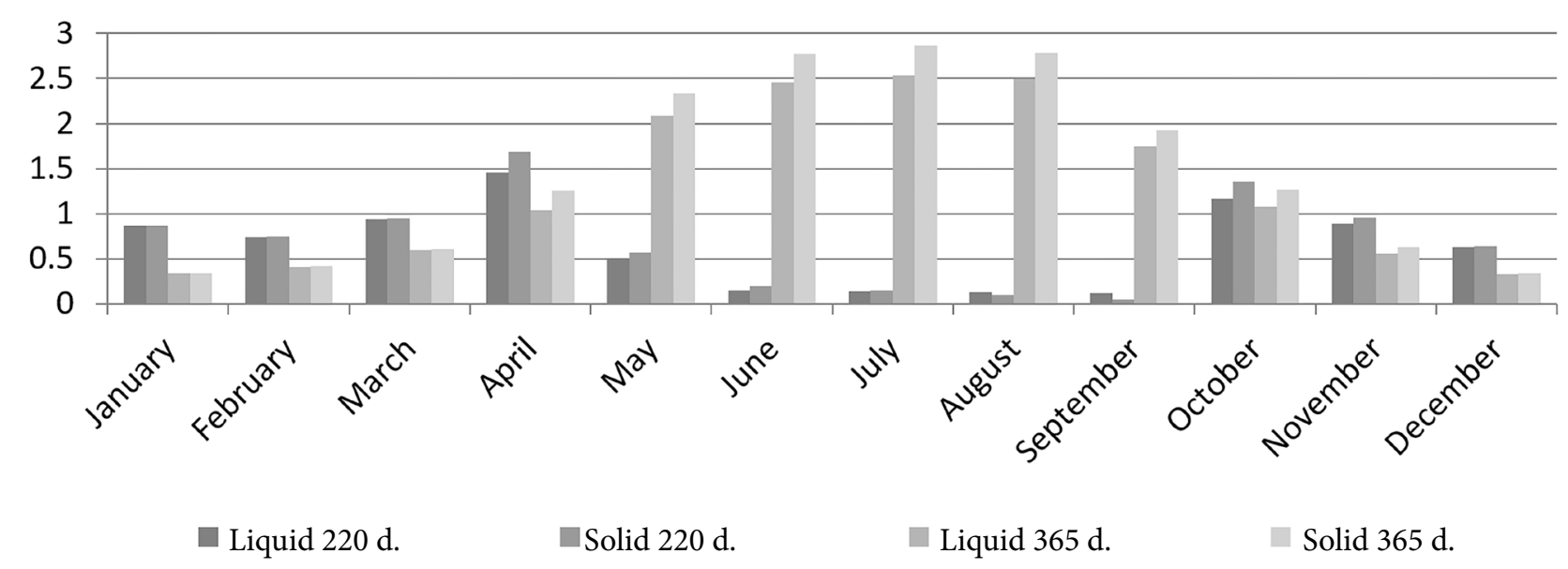

Fig. 3. Ammonia emission from dairy cattle housing and manure storage $\left(\mathrm{kg} \mathrm{a}^{-1} \mathrm{AAP}^{-1} \mathrm{NH}_{3}\right)$ 
Table 3. Ammonia emission and emission factors from dairy cattle housing and manure management.

\begin{tabular}{c|c|c|c|c|c|c}
\hline \multirow{2}{*}{ Housing system } & \multicolumn{3}{|c|}{$\mathrm{EF}_{\mathrm{NH}_{3}} \mathrm{~kg} \mathrm{a}^{-1} \mathrm{AAP} \mathrm{NH}_{3}$} & \multicolumn{2}{c}{$\mathrm{NH}_{3}-\mathrm{N} \mathrm{EF}, \mathrm{kg} \mathrm{NH}_{3}-\mathrm{N} / \mathrm{kg} \mathrm{Nex}$} \\
\cline { 2 - 4 } & \multirow{2}{*}{ Housing } & \multicolumn{2}{|c}{ Storage } & \multirow{2}{*}{ Housing } & \multicolumn{2}{c}{ Storage } \\
\cline { 3 - 5 } \cline { 6 - 7 } & & Liquid & Solid & & Liquid & Solid \\
\hline Tie-stall/pasture & 6.6 & 1.6 & 2.0 & 0.13 & 0.04 & 0.06 \\
\hline Cubicle loose/pasture & 4.2 & 1.6 & 2.3 & 0.09 & 0.04 & 0.06 \\
\hline Cubicle loose & 12.1 & 4.7 & 6.5 & 0.15 & 0.06 & 0.10 \\
\hline
\end{tabular}

The $\mathrm{NH}_{3}$ emission rate for liquid manure ranged from 4.5 to $12.8 \mathrm{~g} \mathrm{~d}^{-1}$ animal $^{-1}$ and for solid manure ranged from 6.0 to $17.9 \mathrm{~g} \mathrm{~d}^{-1}$ animal $^{-1}$. The calculated EFs for the tie-stall housing system shown in Table 3 are lower than the EMEP/EEA Guidebook (2016) values.

No potential for ammonia emissions abatement was found within the investigated cubicle loose housing system based on the zero access to pasture.

\section{Conclusions}

There is a relatively high potential for biomass fuel use in Lithuania. The amount of biomass consumption in the residential sector was increasing and reached about $70 \%$ in 2017 . At the same time the share of natural gas in the residential sector accounts approximately for $20 \%$. Technologyspecific emission factors of $\mathrm{CO}, \mathrm{NO}_{x}$, NMVOC and TSP were evaluated for biomass combustion in fireplaces, manual and automatic boilers. The research results showed that the EF values for $\mathrm{CO}$ varied in the largest range (120-3147 $\left.\mathrm{g} \mathrm{GJ}^{-1}\right)$. The literature review showed that a large range of CO EFs values could be explained by sample moisture and carbon content. NMVOC EF was found to be $80 \mathrm{~g} \mathrm{GJ}^{-1}$ for fireplaces burning wood and wood waste, which is significantly lower than $600 \mathrm{~g} \mathrm{GJ}^{-1}$ of the emission factor presented in the EMEP/EEA Guidebook (2016), but corresponds to the default limits $\left(20-3000 \mathrm{~g} \mathrm{GJ}^{-1}\right)$ provided there. The obtained EFs are not extremely lower than the default values provided in the EMEP/EEA Guidebook (2016), which means that the residential sector will continue to contribute mostly to air pollution as most biomass combustion units are unabated and burning is operating under low temperatures. The switching from biomass to natural gas combustion in the residential sector can be a very long and complex process due to economic conditions and requires a long-term development strategy for Lithuania. The study results presented here indicate that it will be difficult to tackle atmospheric air pollution problems in Lithuania without addressing the replacement of biomass combustion for heating by natural gas- or electricity-based heating in the residential sector.

Keeping of dairy cows in the cubicle loose housing system based on the zero access to pasture can increase ammonia emission from housing and manure storage.

\section{Acknowledgements}

This research was funded by a grant (No. REP18-31) from the Research Council of Lithuania. The research was performed in cooperation with the Environmental Pollution Agency.

\section{References}

[1] Report from the Commission to the European Parliament and the Council assessment of the progress made by Member States towards the national energy efficiency targets for 2020 and towards the implementation of the Energy Efficiency Directive 2012/27/EU as required by Article 24(3) of Energy Efficiency Directive 2012/27/EU (European Commission, 2015).

[2] A. Saffari, N. Daher, C. Samara, D. Voutsa, A. Kouras, E. Manoli, O. Karagkiozidou, C. Vlachokostas, N. Moussiopoulos, M.M. Shafer, J.J. Schauer, and C. Sioutas, Increased biomass burning due to the economic crisis in Greece and its adverse impact on wintertime air quality in Thessaloniki, Environ. Sci. Technol. 47, 13313-13320 (2013).

[3] IEA. Nordic Energy Technology Perspectives: Pathways to a Carbon Neutral Energy Future 
(International Energy Agency, Paris, 2013), https://bit.ly/2FsYwcr

[4] T. Levander and S. Bodin, Controlling Emissions from Wood Burning. Legislation and Regulation in Nordic Countries to Control Emissions from Residential Wood Burning. An Examination of Past Experience (TemaNord, Nordic Council of Ministers, Copenhagen, 2014), https://doi. org.10.6027/TN2014-517

[5] B. Kavolèlis, B. Bakutis, Ammonia emission in cowsheds, Agric. Sci. 1, 45-49 (2004) [in Lithuanian].

[6] S. Pedersen, H. Takai, J.O. Johnsen, J.H.M. Metz, P.W.G. Groot Koerkamp, G.H. Uenk, V.R. Phillips, M.R. Holden, R.W. Sneath, J.L. Short, et al., A comparison of three balance methods for calculating ventilation rates in livestock buildings, J. Agr. Eng. Res. 70, 25-37 (1998).

[7] R. Matulaitis, V. Juškienè, and R. Juška, The effect of floating covers on gas emissions from liquid pig manure, Chil. J. Agric. Res. 72(2), 232-238 (2015).

[8] R. Matulaitis, The Effectiveness of Implements on Mitigation of Greenhouse Gas Emission and Pollution Reduction from Manure, Doctoral Dissertation (Kaunas, 2014) [in Lithuanian].

[9] Livestock Manual (Institute of Animal Science of Lithuanian Veterinary Academy, 2007) [in Lithuanian].
[10]A. Williams, J.M. Jones, L. Ma, and M. Pourkashanian, Pollutants from the combustion of solid biomass fuels, Prog. Energy Combust. Sci. 38(2), 113-137 (2012).

[11]Residential Heating with Wood and Coal: Health Impacts and Policy Options in Europe and North America (World Health Organization, 2015).

[12]V. Suzdalenko, M. Gedrovics, and V. Vitolins, Experimental pilot device for thermal analysis of biomass co-firing, Agron. Res. 12(2), 611-622 (2014).

[13]E.A.T. Yuntenwi, N. MacCarty, D. Still, and J. Ertel, Laboratory study of the effects of moisture content on heat transfer and combustion efficiency of three biomass cook stoves, Energy Sustain. Dev. 12(2), 66-77 (2008).

[14]C.M. Groenestein, N.J. Hutchings, H.D. Haenel, H.B. Amon, H. Menzi, M.H. Mikkelsen, T.H. Misselbrook, C. van Bruggen, T. Kupper, and J. Webb, Comparison of ammonia emissions related to nitrogen use efficiency of livestock production in Europe, J. Clean Prod. 211, 1162-1170 (2019).

[15]R. Bleizgys and L. Baležentienè, Assessments of biogenic gas emission processes in cowsheds, Pol. J. Environ. Stud. 23(4), 1107-1114 (2014).

\title{
BIOMASĖS DEGINIMO NACIONALINIAI EMISIJOS RODIKLIAI NAMŲ IR ŽEMĖS UUKIO SEKTORIUOSE: APŽVALGA IR ATVEJO ANALIZE்
}

\author{
S. Byčenkiene a ${ }^{a}$ I. Konstantinavičiūte ${ }^{\text {b, c }}$, K. Plauškaite ${ }^{a}$, N. Striūgas ${ }^{b}$, T. Vonžodas ${ }^{b}$, M. Sadeckas ${ }^{b}$, \\ N. Pedišius ${ }^{\text {b }}$, R. Juodka ${ }^{\mathrm{d}}$, R. Juška ${ }^{\mathrm{d}}$, V. Juškienè ${ }^{\mathrm{d}}$ \\ ${ }^{a}$ Fiziniu ir technologijos mokslu centras, Vilnius, Lietuva \\ ${ }^{\mathrm{b}}$ Lietuvos energetikos institutas, Kaunas, Lietuva \\ ${ }^{c}$ Kauno technologijos universitetas, Kaunas, Lietuva \\ ${ }^{\mathrm{d}}$ LSMU Gyvulininkystes institutas, Baisogala, Lietuva
}

\section{Santrauka}

Nustatyti nacionaliniai anglies monoksido (CO), azoto oksidų $\left(\mathrm{NO}_{x}\right)$, nemetaninių lakiụjų organinių junginių (NMLOJ), kietųjų dalelių (TSP) ir amoniako $\left(\mathrm{NH}_{3}\right)$ kuro deginimo namų ūkyje ir žemès ūkio sektoriuose šaliai būdingi emisijos rodikliai (angl. emission factors). Nors biomasè yra dažniausiai naudojama biokuro rūšis gyvenamųjų namų segmente, iš kurio ị atmosferą patenka ypač daug teršalų, trūksta moksliniais tyrimais pagrịstų tyrimų, pagrindžiančių konkrečius šaliai būdingus emisijos veiksnius Lietuvoje. Šiame tyrime daugiausia dèmesio buvo skiriama nacionaliniu emisijos rodiklių verčių nustatymui biomasès deginimo gyvenamųjų namų ir žemès ùkio sektoriuose taikant keturių pakopų metodiką. 